\title{
The relative contributions of forest growth and areal expansion to forest biomass carbon
}

\author{
P. Li ${ }^{1, *}$, J. Zhu ${ }^{1, *}$, H. Hu ${ }^{2}$, Z. Guo ${ }^{1,3}$, Y. Pan ${ }^{4}$, R. Birdsey ${ }^{4}$, and J. Fang ${ }^{1}$ \\ ${ }^{1}$ Department of Ecology, College of Urban and Environmental Sciences, and Key Laboratory for Earth \\ Surface Processes, Ministry of Education, Peking University, Beijing 100871, China \\ ${ }^{2}$ State Key Laboratory of Vegetation and Environmental Change, Institute of Botany, Chinese Academy of \\ Sciences, Beijing 100093, China \\ ${ }^{3}$ National Satellite Meteorological Center, China Meteorological Administration, Beijing 100081, China \\ ${ }^{4}$ US Department of Agriculture Forest Service, Newtown Square, PA 19073, USA \\ *These authors contributed equally to this work.
}

Correspondence to: J. Fang (jyfang@urban.pku.edu.cn)

Received: 11 April 2015 - Published in Biogeosciences Discuss.: 30 June 2015

Revised: 6 December 2015 - Accepted: 7 January 2016 - Published: 19 January 2016

\begin{abstract}
Forests play a leading role in regional and global terrestrial carbon $(\mathrm{C})$ cycles. Changes in $\mathrm{C}$ sequestration within forests can be attributed to areal expansion (increase in forest area) and forest growth (increase in biomass density). Detailed assessment of the relative contributions of areal expansion and forest growth to $\mathrm{C}$ sinks is crucial to reveal the mechanisms that control forest $\mathrm{C}$ sinks and it is helpful for developing sustainable forest management policies in the face of climate change. Using the Forest Identity concept and forest inventory data, this study quantified the spatial and temporal changes in the relative contributions of forest areal expansion and increased biomass growth to China's forest biomass C sinks from 1977 to 2008. Over the last 30 years, the areal expansion of forests has been a larger contributor to $\mathrm{C}$ sinks than forest growth for planted forests in China (62.2\% vs. $37.8 \%$ ). However, for natural forests, forest growth has made a larger contribution than areal expansion $(60.4 \%$ vs. $39.6 \%)$. For all forests (planted and natural forests), growth in area and density has contributed equally to the total $\mathrm{C}$ sinks of forest biomass in China (50.4\% vs. $49.6 \%$ ). The relative contribution of forest growth of planted forests showed an increasing trend from an initial $25.3 \%$ to $61.0 \%$ in the later period of 1998 to 2003 , but for natural forests, the relative contributions were variable without clear trends, owing to the drastic changes in forest area and biomass density over the last 30 years. Our findings suggest that afforestation will continue to increase the $\mathrm{C}$ sink
\end{abstract}

of China's forests in the future, subject to sustainable forest growth after the establishment of plantations.

\section{Introduction}

As the largest terrestrial ecosystem, forests occupy around $30 \%$ of the global land surface area (Bonan, 2008; Pan et al., 2013) and play a dominant role in regional and global carbon (C) cycles because of their huge capacity for $\mathrm{C}$ storage and high productivity (Leith and Whittaker, 1975; Malhi et al., 2002; Pan et al., 2011). Forests can be sources of atmospheric $\mathrm{CO}_{2}$ following anthropogenic and natural disturbances, but they can also function as $\mathrm{C}$ sinks to sequester or conserve large quantities of $\mathrm{C}$ during regrowth after disturbances (Brown et al., 1996, 1999; Brown and Schroeder, 1999; Hu and Wang, 2008; Pan et al., 2011). Therefore, investigation of the possible mechanisms of forest $\mathrm{C}$ dynamics is of scientific and political importance (Watson et al., 2000; Fang et al., 2001, 2014a, b; Janssens et al., 2003; Nabuurs et al., 2003; Birdsey et al., 2006; McKinley et al., 2011).

China has the fifth-largest forest area of any country in the world (Ministry of Forest of China, 2010) and encompasses a variety of forest biomes, from boreal forests in the north to subtropical/tropical evergreen broadleaf forests in the south (Fang et al., 2010). With the implementation of national afforestation and reforestation programs since the late 1970s, 
such as the Three-North Protective Forest Program, the Natural Forest Conservation Program, and the Wetland Restoration Program, forest ecosystems in China are credited to have made a significant contribution to regional and global $\mathrm{C}$ sinks in recent decades (Fang et al., 2001, 2014a; Fang and Chen, 2001; Lei, 2005; Xu et al., 2010; Pan et al., 2011; Guo et al., 2013). Based on the biomass expansion factor (BEF) method and China's forest inventory data, Guo et al. (2013) estimated the spatiotemporal changes in the forest biomass $\mathrm{C}$ sink from 1977 to 2008 and concluded that the annual biomass $C$ sink $\left(70.2 \mathrm{Tg} \mathrm{C} \mathrm{yr}^{-1}, 1 \mathrm{Tg}=10^{12} \mathrm{~g}\right.$ ) offset $7.8 \%$ of the contemporary $\mathrm{CO}_{2}$ emissions in the country.

In general, increased forest biomass $\mathrm{C}$ sinks are driven by forest areal expansion and forest regrowth. The Forest Identity concept, developed for separating the variables of change in forest area, biomass, and C densities (Kauppi et al., 2006; Waggoner, 2008), is useful to develop a method to estimate the change in forest biomass $\mathrm{C}$ stock driven by different causes. Using the Forest Identity concept, Shi et al. (2011) evaluated the status of change in China's forests and showed that the increase in $\mathrm{C}$ sequestration was attributable to the increase in forest area and growing stock density over the last 3 decades. More recently, to explore the mechanisms that drive forest $\mathrm{C}$ sinks in east Asia, Fang et al. (2014a) used the Forest Identity approach to estimate the relative contributions of changing forest area and forest $\mathrm{C}$ density to the forest biomass C sink in China, Japan, and South Korea. These studies found that the relative contributions of the changing factors varied among countries and forest origin (planted vs. natural forests). Specifically, it was reported that forest areal expansion made a larger contribution to $\mathrm{C}$ sinks than increased biomass density for all forests. However, the study of Fang et al. (2014a) did not analyze the spatial and temporal variability in the relative contributions of forest areal expansion and increased biomass density to China's forest C sinks. In this study, we used the Forest Identity concept and forest inventory data to quantify the spatial and temporal difference in the relative contributions of forest areal expansion and increased biomass density to China's forest $\mathrm{C}$ sinks during the past 30 years in detail. Furthermore, we discussed the primary reasons for reduced biomass $\mathrm{C}$ stocks of natural forests in some provinces of China.

\section{Data and methods}

\subsection{Forest inventory data}

China's forest inventory data (CFID) for the periods $1977-$ 1981, 1984-1988, 1989-1993, 1994-1998, 1999-2003, and 2004-2008 were used in this study (Chinese Ministry of Forestry, 1983, 1989, 1994, 2000, 2005, 2010). These inventories were compiled from more than 250000 plots (160000 permanent sample plots plus 90000 temporary sample plots) across the country. Systematic sampling with a grid of $2 \mathrm{~km}$ by $2 \mathrm{~km}$ or $4 \mathrm{~km}$ by $4 \mathrm{~km}$ and an area of $10 \mathrm{~m}$ by $10 \mathrm{~m}$ was used depending on forest region. In CFID, China's forests were classified into three categories: stands (including natural and planted forests), economic forests (woods with the primary objective of the production of fruits, edible oils, drinks, flavorings, industrial raw materials, and medicinal materials), and bamboo forests (Guo et al., 2013). In the present study, "forest" refers only to a "forest stand" with canopy coverage $\geq 20 \%$ and therefore excludes economic and bamboo forests (Fang et al., 2007). At the provincial level, the inventories documented detailed information on age class, area, and volume for each forest type, in which forest area was estimated by the "ratio method" in the systematic sampling across each province (see Appendix E). To investigate spatial variation, we divided the national land area into six broad regions - north, northeast, east, south central, southwest, and northwest - consistent with the method of Fang et al. (2001; Fig. 1c).

\subsection{Calculation of forest biomass $\mathrm{C}$ stocks}

In this study, we used the continuous biomass expansion factor (BEF, defined as the ratio of stand biomass to timber volume) method with parameters for each forest type taken from Guo et al. (2013) to calculate forest biomass in China, because CFID only report the forest area and timber volume for each forest type. The BEF method was first developed from the allometric relationships between forest biomass and forest timber volume (Fang et al., 1998; Brown and Schroeder, 1999), then evolved to be the continuous BEF method based on the reciprocal equation expressing the BEF-timber volume relationship (Fang et al., 1998, 2001, 2005):

$\mathrm{BEF}=a+b / x$.

In Eq. (1), $x$ is the timber volume per unit area $\left(\mathrm{m}^{3} \mathrm{ha}^{-1}\right)$, and $a$ and $b$ are constants for each specific forest type. With this simple BEF approach, one can easily calculate regional or national forest biomass based on direct field measurements and forest inventory data. Calculations with the BEF method are well documented by Fang et al. (2001, 2014a) and the BEF method has been previously applied to estimate China's forest stand biomass (Fang et al., 2007; Guo et al., 2013). In this study, the ratio of 0.5 was used to convert biomass to $\mathrm{C}$ stock (Fang et al., 2001).

\subsection{Calculation of the relative contributions of forest areal expansion and increased biomass density}

Using the Forest Identity concept (Kauppi et al., 2006; Waggoner, 2008), Fang et al. (2014a) proposed a method to separate the relative contribution of forest areal expansion and forest growth to changes in forest biomass stock (or biomass C sink/source). According to Fang et al. (2014a), the relationships among forest area $(A)$, biomass $C$ density $(D)$, and total biomass $C$ stock $(M)$ can be formulated by Eq. (1), and 

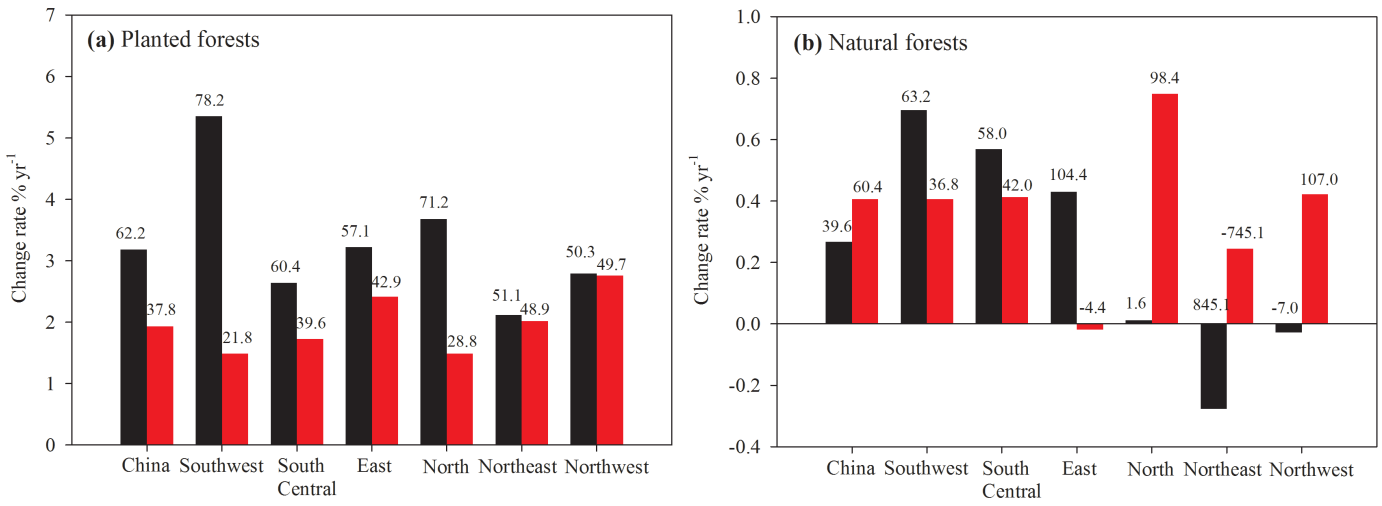

(c)

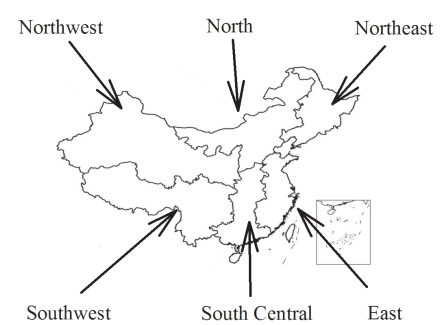

Figure 1. Rate of change and the relative contributions of forest area and biomass density to carbon sinks in planted (a) and natural (b) forests in six broad regions of China for the period 1977-2008. The division of these six broad regions is indicated in (c). Bars and numbers above represent the rates of change and the relative contributions of forest area (in black) and carbon density (in red), respectively.

their respective rates of change $(a, d$, and $m)$ over time $(t)$ can be derived from Eqs. (3) and (4).

$M=A \times D$

Because $\ln (M)=\ln (A)+\ln (D)$, the relative change rates of $M, A$, and $D$ over time ( $m, a$, and $d)$ are the direct result of differentiating the equation over time:

$\frac{1}{M} \frac{\mathrm{d} M}{\mathrm{~d} t}=\frac{1}{A} \frac{\mathrm{d} A}{\mathrm{~d} t}+\frac{1}{D} \frac{\mathrm{d} D}{\mathrm{~d} t}$

or $\frac{\mathrm{d} \ln (M)}{\mathrm{d} t}=\frac{\mathrm{d} \ln (A)}{\mathrm{d} t}+\frac{\mathrm{d} \ln (D)}{\mathrm{d} t}$.

Let the real change rate ( $m, a$, and $d$ ) among two inventory periods be approximately equal to the change rate of its natural logarithm:

$m \approx \frac{\mathrm{d} \ln (M)}{\mathrm{d} t}, a \approx \frac{\mathrm{d} \ln (A)}{\mathrm{d} t}, d \approx \frac{\mathrm{d} \ln (D)}{\mathrm{d} t}$.

Then $m=a+d$, where $M, A$, and $D$ represent total biomass C stock (Tg C or Pg C, $1 \mathrm{Tg}=10^{12} \mathrm{~g}, 1 \mathrm{Pg}=10^{15} \mathrm{~g}$ ), forest area (ha), and biomass $\mathrm{C}$ density $\left(\mathrm{MgC} \mathrm{ha}^{-1}, 1 \mathrm{Mg}=10^{6} \mathrm{~g}\right)$, respectively; and $m, a$, and $d$ are the corresponding derivatives (or rate of change) of these attributes over time $(t)$.

The rates $(m, a$, and $d$ ) can be approximately calculated by the following formula (Eq. 4):

change rate $\left(\% y r^{-1}\right) \approx \frac{2\left(X_{2}-X_{1}\right)}{\left(X_{2}+X_{1}\right)\left(t_{2}-t_{1}\right)} 100 \%$, where $X_{1}$ and $X_{2}$ represent the forest area $(A)$ or biomass $\mathrm{C}$ density $(D)$ in the two forest inventories, which started at $t_{1}$ and $t_{2}$, respectively.

Thus, the relative contribution of change in forest area $\left(R_{\mathrm{a}}\right.$, $\%)$ and change in biomass density $\left(R_{\mathrm{d}}, \%\right)$ to the change in forest biomass $\mathrm{C}$ stock can be expressed as Eq. (5):

$R_{\mathrm{a}}(\%)=a / m \times 100 ; R_{\mathrm{d}}(\%)=d / m \times 100$.

The carbon sinks attributing to areal expansion $\left(M_{a}\right)$ or growth in forest density $\left(M_{d}\right)$ were derived from the multiplication of the relative contribution (\%) and the total carbon sinks:

$M_{\mathrm{a}}=R_{\mathrm{a}}(\%) \times \delta M ; M_{\mathrm{d}}=R_{\mathrm{d}}(\%) \times \delta M$.

For all forests, the relative contributions $(R, \%)$ of areal expansion or growth in density were calculated by the ratio of carbon sinks in planted and natural forests to the carbon sinks of all forests (Eq. 7):

$$
\begin{aligned}
& R_{\mathrm{a}}(\%)=\left\{M_{\mathrm{a}}(\text { planted })+M_{\mathrm{a}}(\text { natural })\right\} \times 100 / \delta M ; \\
& R_{\mathrm{d}}(\%)=\left\{M_{\mathrm{d}}(\text { planted })+M_{\mathrm{d}}(\text { natural })\right\} \times 100 / \delta M .
\end{aligned}
$$

\section{Results}

\subsection{Spatial pattern of the relative contributions of forest area and biomass density to $\mathrm{C}$ sinks}

Figure 1 shows the results of the national and regional relative contributions of forest areal expansion $(a)$ and increased 
biomass $\mathrm{C}$ density $(d)$ to the $\mathrm{C}$ sinks of planted and natural forests between the late 1970s (1977-1981) and the 2000s (2004-2008).

Planted forests have functioned as $\mathrm{C}$ sinks $(817.6 \mathrm{Tg} \mathrm{C})$ in the past 3 decades (Appendix A), and areal expansion has made a larger contribution to the $\mathrm{C}$ sink than has the change in biomass density in all regions (Fig. 1a). At the national level, the area of planted forests increased at a mean rate of $3.18 \% \mathrm{yr}^{-1}$ and contributed $62.2 \%$ to biomass $\mathrm{C}$ sinks of planted forests between 1977 and 2008. Among the six regions, the largest contribution of areal expansion (78.2\%) was in the southwest, followed by the north $(71.2 \%)$, south central $(60.4 \%)$, and east (57.1\%) regions. The contributions of areal expansion and increased biomass density were approximately equal to $50 \%$ in the northeast and northwest regions.

In contrast to planted forests, the areal expansion of natural forests was found to be a smaller contributor to the $\mathrm{C}$ sink $(892.1 \mathrm{TgC})$ than increased biomass density $(39.6 \%$ vs. $60.4 \%$ ) at the national level, with $a$ and $d$ of 0.27 and $0.41 \% \mathrm{yr}^{-1}$, respectively (Fig. 1b). However, the patterns were not consistent at the regional level: forest areal expansion made a larger contribution to the $\mathrm{C}$ sink than did increased biomass density in the southwest $(63.2 \%$ vs. $36.8 \%)$ and south central $(58.0 \%$ vs. $42.0 \%)$ regions, and in the east region, areal expansion was responsible for all of the $\mathrm{C}$ sink $(104.0 \%)$, because the $\mathrm{C}$ density of natural forests has shrunk by $0.49 \%$ over the last 30 years $\left(d=-0.02 \% \mathrm{yr}^{-1}\right)$ (also see Appendix B). Conversely, in north and northwest China, increased $\mathrm{C}$ density dominated the $\mathrm{C}$ sinks, with contributions of 98.4 and $107.0 \%$, respectively. In the northeast region, the area of natural forest has decreased at a mean rate of $0.27 \% \mathrm{yr}^{-1}$, which exceeds the increase in $\mathrm{C}$ density $\left(d=0.24 \% \mathrm{yr}^{-1}\right)$, and has fully ultimately contributed to the $\mathrm{C}$ source of the natural forest in this region.

On the whole, for all forests (planted and natural forests), the biomass $\mathrm{C}$ sink attributing to areal expansion and growth in density was 862.3 and $847.5 \mathrm{TgC}$, respectively, indicating an equal relative contribution to the total forest biomass $\mathrm{C}$ sinks from these two driving agents in the study period ( $50.4 \%$ vs. $49.6 \%$, Table 1$)$.

\subsection{Temporal dynamics of the relative contributions of forest area and biomass density to $\mathrm{C}$ sinks}

We further explored changes of the relative contributions of forest areal expansion and biomass density to $\mathrm{C}$ sinks of Chinese forests from 1977 to 2008 (Fig. 2), by calculating the change rates $(a$ and $d)$ and the relative contribution rates for the six forest inventory periods.

For planted forests, the rate of change in forest area was highest in the 1980s (1981-1988; Fig. 2a) with a mean increase of $5.45 \% \mathrm{yr}^{-1}$, then it decreased until the late $1990 \mathrm{~s}$ (1993-1998), and thereafter increased in the 2000s. Over the same period, forest biomass $\mathrm{C}$ density experienced slow but relatively steady enhancement from the early 1980 s to the early 2000s (Fig. 2a), reaching the highest rate of increase in the period $1998-2003\left(d=2.33 \% \mathrm{yr}^{-1}\right)$, and then decreased abruptly to a low rate of increase $\left(0.60 \% \mathrm{yr}^{-1}\right)$ in the late 2000s (2003-2008). The relative contribution of areal expansion declined from $74.4 \%$ between 1981 and 1988 to $39.0 \%$ between 1998 and 2003, whereas the contribution of increased C density increased from 25.6 to $61.0 \%$ over the same period (Fig. 2c). After 2003, on account of the rapid growth of forest area (Fig. 2a), the contribution of areal expansion increased and became the dominant contributor to the C sink of China's planted forests $(87.7 \%$ vs. $12.3 \%$ for 2003-2008).

In contrast to planted forests, the areal expansion and increase of $\mathrm{C}$ density in natural forests were more dynamic, having relatively lower rates of change less than $1.5 \% \mathrm{yr}^{-1}$ over the study period (Fig. 2b). Furthermore, negative growth was observed in forest area $\left(a=-1.80 \% \mathrm{yr}^{-1}\right.$ for 1993-1998) and biomass $C$ density $(d=-0.08$ and $-0.20 \% \mathrm{yr}^{-1}$ for $1981-1988$ and $1998-2003$, respectively) in natural forests over the study period. Aligning with dynamic rates of change, the relative contribution of forest areal expansion showed a generally decreasing trend from 1981 $(366.7 \%)$ to $2008(70.2 \%)$, in contrast to the increase in C density (Fig. 2d). In addition, areal expansion always made a greater impact on the carbon sink than did the change in $\mathrm{C}$ density in most of the inventory periods, except for the period of 1988-1993, when increased C density made a slightly larger contribution than areal expansion (51.1\% vs. $48.9 \%)$.

\subsection{Causes of $\mathrm{C}$ loss of natural forests at the provincial level}

Over the past 3 decades, planted forests have functioned as $\mathrm{C}$ sinks in all provinces of China (Appendix C). However, three provinces showed a distinct $\mathrm{C}$ loss in their natural forests over the study period (Appendix D): Heilongjiang (located in northeast), Gansu (northwest), and Fujian (east). Among these provinces, Heilongjiang contained the largest area of natural forest $\left(1817.9 \times 10^{4} \mathrm{ha} ; 1977-1981\right)$ in China, of which the biomass $\mathrm{C}$ stock shrank by $47.2 \mathrm{Tg} \mathrm{C}$ (783.7 Tg C during $1977-1981$ to $736.5 \mathrm{Tg} C$ in the $2000 \mathrm{~s}$ ). The $\mathrm{C}$ stocks of natural forests in Gansu and Fujian also underwent a decline from 87.0 and $132.8 \mathrm{TgC}$ in the 1970 s to 82.4 and $128.9 \mathrm{TgC}$ in the $2000 \mathrm{~s}$, respectively. Here, we focused on these three provinces to explore the reasons for the declines in $\mathrm{C}$ stock of the natural forests over the past 30 years by quantifying the relative contributions of changes in forest area and $\mathrm{C}$ density.

Among the three provinces, biomass $\mathrm{C}$ density of natural forests increased more or less from 1977 to 2008; the rate of change was highest in Gansu $\left(d=0.66 \% \mathrm{yr}^{-1}\right)$, whereas only slight increases were observed in Heilongjiang and $\mathrm{Fu}-$ jian (Fig. 3, Appendix E). Conversely, the forest area in these provinces experienced more obvious decreases. The forest 
Table 1. Summary of forest variables for planted, natural, and all forests between the forest inventory periods of 1977-1981 and 2004-2008.

\begin{tabular}{|c|c|c|c|c|c|c|c|c|c|c|c|c|}
\hline \multirow[b]{2}{*}{ Forest type } & \multicolumn{3}{|c|}{ 1977-1981 } & \multicolumn{3}{|c|}{ 2004-2008 } & \multirow[b]{2}{*}{$\left(\% \mathrm{yr}^{-1}\right)$} & \multirow[b]{2}{*}{$\begin{array}{r}d \\
\left(\% \mathrm{yr}^{-1}\right)\end{array}$} & \multirow[b]{2}{*}{$\begin{array}{r}R_{\mathrm{a}} \\
(\%)\end{array}$} & \multirow[b]{2}{*}{$\begin{array}{r}R_{\mathrm{d}} \\
(\%)\end{array}$} & \multirow[b]{2}{*}{$\begin{array}{r}M_{\mathrm{a}} \\
(\mathrm{TgC})\end{array}$} & \multirow[b]{2}{*}{$\begin{array}{r}M_{\mathrm{d}} \\
(\mathrm{Tg} \mathrm{C})\end{array}$} \\
\hline & $\begin{array}{r}\text { Area } \\
\left(10^{4} \text { ha }\right)\end{array}$ & $\begin{array}{r}\text { Density } \\
\left(\mathrm{MgCha}^{-1}\right)\end{array}$ & $\begin{array}{r}\text { Carbon stock } \\
(\mathrm{Tg} C)\end{array}$ & $\begin{array}{r}\text { Area } \\
\left(10^{4} \text { ha }\right)\end{array}$ & $\begin{array}{r}\text { Density } \\
\left(\mathrm{MgCha}^{-1}\right)\end{array}$ & $\begin{array}{r}\text { Carbon stock } \\
(\mathrm{Tg} C)\end{array}$ & & & & & & \\
\hline Planted forests & 1595 & 15.6 & 249.5 & 3999 & 26.7 & 1067.1 & 3.18 & 1.93 & 62.2 & 37.8 & 508.8 & 308.8 \\
\hline Natural forests & 10755 & 41.5 & 4467.8 & 11559 & 46.4 & 5360.0 & 0.27 & 0.41 & 39.6 & 60.4 & 353.5 & 538.7 \\
\hline All forests & 12350 & 38.2 & 4717.4 & 15558 & 41.3 & 6427.1 & 0.85 & 0.29 & 50.4 & 49.6 & 862.3 & 847.5 \\
\hline
\end{tabular}

* $a$ : change rate of forest area; $d$ : change rate of forest density; $R_{\mathrm{a}}$ : relative contribution of areal expansion to carbon sink; $R_{\mathrm{d}}$ : relative contribution of forest regrowth to carbon sink; $M_{\mathrm{a}}$ : carbon sinks attributing to areal area expansion; $M_{\mathrm{d}}$ : carbon sinks attributing to growth in density.
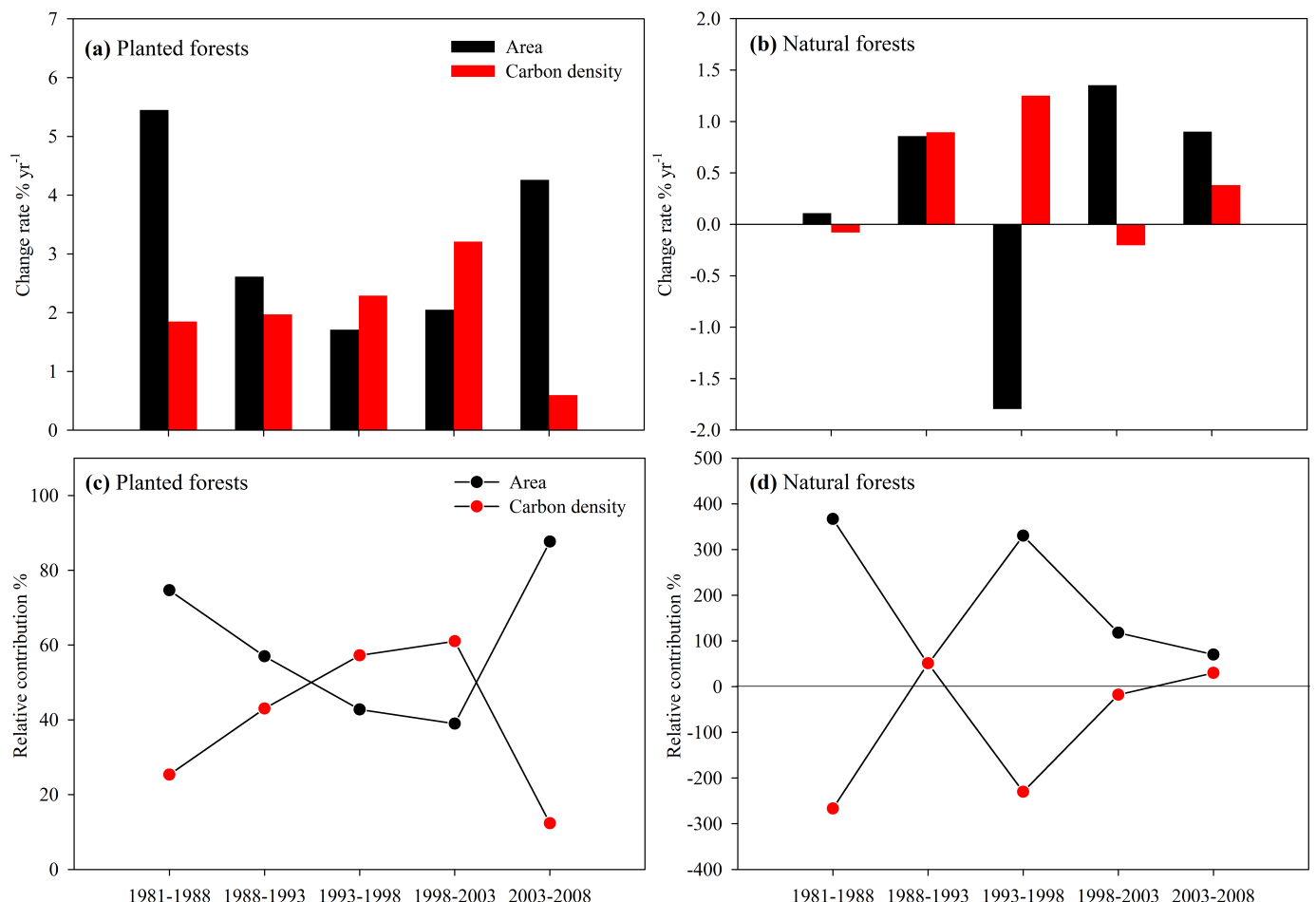

1981-1988 1988-1993 1993-1998 1998-2003 2003-2008

Figure 2. Relative contributions and the dynamics of areal expansion and forest growth to carbon sinks in planted (a and c) and natural (b and d) forests of China in the period 1977-2008. Bars and points represent the rates of change and the relative contributions of forest area (in black) and carbon density (in red), respectively.

area in Heilongjiang has decreased dramatically by 133.6 $10^{4}$ ha $\left(a=-0.28 \% \mathrm{yr}^{-1}\right)$ over the last 30 years, followed by that of Gansu $\left(41.1 \times 10^{4} \mathrm{ha}, a=-0.85 \% \mathrm{yr}^{-1}\right)$ and $\mathrm{Fu}-$ jian $\left(12.9 \times 10^{4} \mathrm{ha}, a=-0.14 \% \mathrm{yr}^{-1}\right)$. Detailed analysis of the temporal dynamics of change rates in these provinces demonstrated that most of the decline in forest area occurred between 1981 and 1998 (Fig. 4a, c and e), whereas the contributions of forest area to the $\mathrm{C}$ stock change of these provinces increased rapidly, attaining their highest values (Fig. 4b, d and f). Overall, the rapid decline in forest area has exceeded the contribution of increased $\mathrm{C}$ density, and has ultimately caused the $\mathrm{C}$ loss in these provinces (Figs. 3 and 4).

\section{Discussion}

\subsection{Relative contributions of changes in forest area and biomass density to the $\mathbf{C}$ sink in China's forests}

Over the past 3 decades, areal expansion and forest growth have increased $\mathrm{C}$ stocks in both planted $(817.6 \mathrm{Tg} \mathrm{C})$ and natural (892.1 Tg C) forests. However, the mechanisms underlying the $\mathrm{C}$ sinks differed markedly with various effects from these two driving agents (Fig. 5).

For planted forests, areal expansion made a larger contribution than did biomass growth at both national and regional levels (Fig. 1a). Having benefited from the implementation of national afforestation and reforestation projects since the 1970s (Fang et al., 2001; Li, 2004; FAO, 2006; Wang et al., 2007), the area of planted forest in China has expanded dramatically from $16.95 \times 10^{6}$ to $24.05 \times 10^{6}$ ha over the last 30 


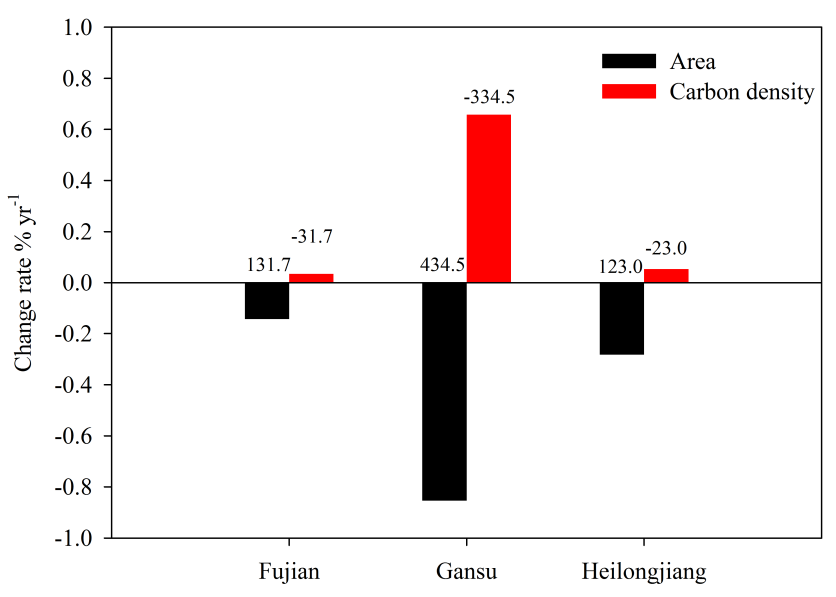

Figure 3. Rate of change and the relative contributions of changes in forest area and carbon density of natural forests to carbon loss in three provinces of China in the period 1977-2008. Bars and numbers above represent the rates of change and the relative contributions of forest area (in black) and carbon density (in red), respectively.

years (Appendix B). Meanwhile, the growth of these young forests also made a significant contribution to $\mathrm{C}$ sequestration; the biomass density of planted forest increased by $71.2 \%$ from an initial density of 15.6 to $26.7 \mathrm{MgC} \mathrm{ha}^{-1}$ in the late 2000s (2004-2008), which indicates that planted forest could still sequester additional $\mathrm{C}$ through future growth (Guo et al., 2010; Xu et al., 2010).

Compared to planted forests, the growth of existing natural forests was a larger contributor to the $\mathrm{C}$ sink than areal expansion at the national level $(60.4 \%$ vs. $39.6 \%$ for density change vs. area change), because the biomass density increased more rapidly, with a net gain of $4.8 \mathrm{MgCha}^{-1}$ $(11.6 \%)$, than the forest area (7.4\%). Regional disparities were also apparent. Forest growth dominated the $\mathrm{C}$ sink in the north and northwest regions, but made a smaller contribution in the southwest, south central, and east regions (Fig. 1b). The inconsistent patterns in the contributions of forest growth and areal expansion may be associated with differences in forest management policies, harvest intensity, and climatic factors (e.g., the warming climate, increasing summer precipitation, elevated $\mathrm{CO}_{2}$, and natural nitrogen deposition) among these regions (Fang et al., 2004, 2014b; Magnani et al., 2007; Du et al., 2014). For instance, southern and southwest China has experienced a drier and hotter climate in the last 3 decades, while northern China has become wetter and has had longer growing seasons (Peng et al., 2011), which may effectively contribute to the enhanced $\mathrm{C}$ densities in the northern regions.
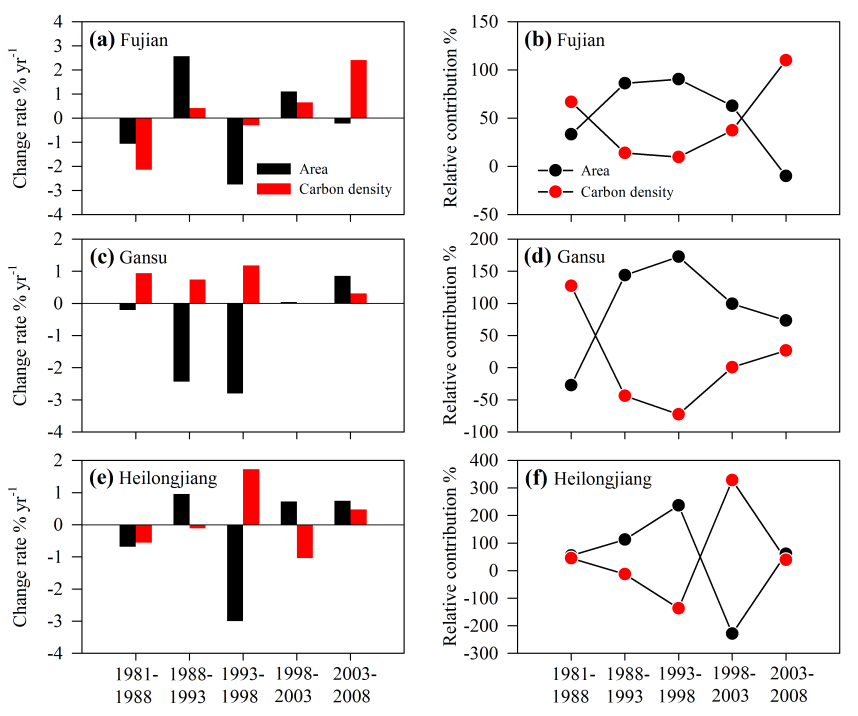

Figure 4. Rate of change (a, $\mathbf{c}$, and $\mathbf{e})$ and relative contributions of changes (b, d, and f) in forest area and carbon density of natural forests to carbon loss in three provinces of China in the period 1977-2008. Bars and points represent the rates of change and the relative contributions of forest area (in black) and carbon density (in red), respectively.

\subsection{Dynamics of areal expansion and forest growth in planted and natural forests}

It is generally recognized that areal expansion and forest growth are closely associated with the intensity of reforestation and loss of forest cover (e.g. deforestation, industrial harvest, or natural disturbance). Therefore, implementation of forest management policies may have a strong impact on forest $\mathrm{C}$ sequestration via the introduction of a variety forest projects in a country (Brown et al., 1997; Fang et al., 2001; Birdsey et al., 2006; Kauppi et al., 2006). Naturally, different forest management policies and projects would alter the rate of change in forest expansion and growth at different levels, ultimately leading to mechanisms regulating $\mathrm{C}$ sequestration among natural and planted forests.

The decline followed by an increasing trend in the areal expansion in planted forests was strongly associated with the stages of forest restoration projects conducted in China (Fig. 2a). The nationwide reforestation projects in China can be divided into two stages. Aiming to provide resistance to harsh weathers and environmental protection, the first stage was initiated in the 1970s and peaked in the 1980s; the forests established in this period were specifically targeted for environmental protection in some regions or provinces $(\mathrm{Li}$, 2004; Wang et al., 2007). The second stage, initiated from the late 2000s, included six major forestry projects: Natural Forest Conservation Projects (2000), Three-North Protection Forest System (2000), Wildlife and Nature Reserve Construction Projects (2001), Grain for Green Project (2002), Fast-growing Forests in Key Areas Projects (2002), and 


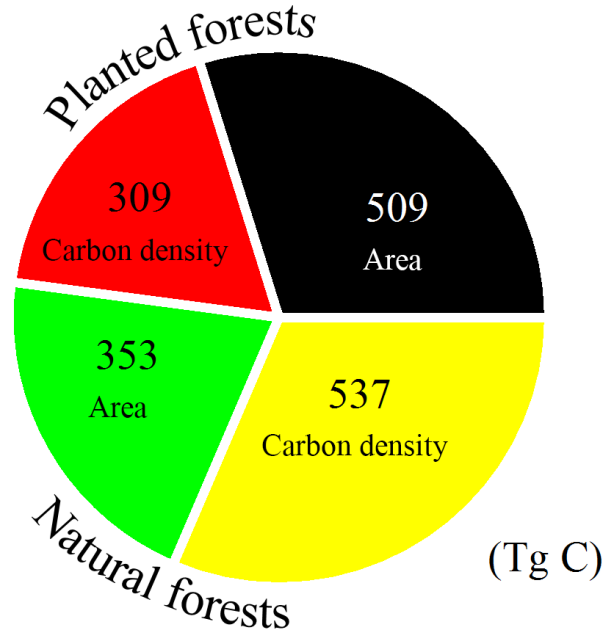

Figure 5. Summary of the forest biomass carbon sinks attributing to areal expansion and increase in carbon density for planted and natural forests of China in the period 1977-2008.

the Beijing-Tianjin-Hebei Sandstorm Source Treatment Project (Lei, 2005; Liu, 2006; Wang et al., 2007). Compared with the first stage, the second stage covered more than $97 \%$ of counties in the country, and was designed for a broader range of ecosystem services and multiple goals (e.g., biodiversity conservation and development of fast-growing plantations for industry). Rapid and concentrated afforestation projects would indeed enlarge the forest area and enhance the relative contribution of areal expansion to the $\mathrm{C}$ sink in a short period (i.e., in the periods 1981-1988 and 2003-2008; Fig. 2c). However, once the projects were slowed down or finished, forest growth would take over, accelerating under favorable growth conditions and effective management and leading to improvement in the relative contribution of $\mathrm{C}$ density to the $\mathrm{C}$ sink over a longer time frame (Fig. 2c).

The natural forests in China constitute a large $\mathrm{C}$ stock, of which its proportion to total forest biomass $\mathrm{C}$ stock was $83.40 \%$ in the late 2000s (2004-2008). However, natural forests have faced long-term logging pressure (e.g. timber extraction and farming; Li, 2004; Lei, 2005), in addition to other degrading factors, such as increased wildfires or extreme weather events (Shi, 2011). In the present study, owing to the drastic changes in forest area and biomass density over the last 30 years (Fig. 2b), the relative contributions were variable without clear trends (Fig. 2d). For instance, in the period 1993-1998, biomass density increased from 43.2 to $46.0 \mathrm{MgCha}^{-1}\left(d=1.25 \% \mathrm{yr}^{-1}\right)$, but forest area decreased by $0.97 \times 10^{6} \mathrm{ha}\left(a=-1.79 \% \mathrm{yr}^{-1}\right)$ in the same period (Appendix C, Fig. 2b). Thus, areal contraction was responsible for the net C loss in the late 1990s. Analysis of $\mathrm{C}$ sinks at the provincial level also revealed that forest area declined at a relatively higher rate than the increase in biomass density in some provinces, making areal reduction the primary reason for C loss in natural forests (Fig. 3).
Notably, since the late 1990s (1994-1998), natural forests in China have functioned as a persistent $\mathrm{C}$ sink, probably owing to the implementation of the nationwide Natural Forest Conservation Project which started in 1998 (Appendix C; Lei, 2005; Ministry of Forestry of China, 2009; Guo et al., 2013). Subsequently, the relative contribution of changes in biomass has shown a constant increase (Fig. 2d).

\subsection{Uncertainty of estimates}

Uncertainties in our studies mainly arise from the quality of forest area and timber volume data in the forest inventories and the estimation of national biomass stocks using the BEF method. On the one hand, precision in the forest area and in the timber volume data was required to be $>90 \%$ in almost all provinces (> $85 \%$ in Beijing, Shanghai, and Tianjin; Xiao, $2005)$. On the other hand, the $R^{2}$ values of the BEF equations used to convert timber volume to biomass for most dominant tree species or forest types exceeded 0.8 (Fang et al., 2014a). Therefore, the data and method used in the present study show relatively high precision. Previous studies have reported that the estimation error of biomass stocks at the national level is expected to be less than $3 \%$ in China (Fang et al., 1996).

\section{Conclusions}

With the implementation of national afforestation and reforestation programs since the late 1970s, China is credited with having made a significant contribution to regional and global $\mathrm{C}$ sinks in recent decades. Using forest identity and CFID, this study quantified in detail the relative contributions of forest areal expansion and increased biomass density to China's forest $\mathrm{C}$ sinks during the past 30 years. Our findings suggested that the mechanisms underlying the $\mathrm{C}$ sinks for natural and planted forests differed markedly with various effects from these two driving agents. The areal expansion of forests was a larger contributor to $\mathrm{C}$ sinks than forest growth for all forests and planted forests, while forest growth (e.g. increased biomass density) made a larger contribution for natural forests. For all forests, growth in area and density each contributed equally to the total $\mathrm{C}$ sinks in forest biomass in China (50.4\% vs. $49.6 \%)$. Furthermore, the increasing trend in the relative contribution of forest growth to $\mathrm{C}$ sinks for planted forests highlights that afforestation will continue to increase the $\mathrm{C}$ sink of China's forests in the future, subject to persistently increasing forest growth after the establishment of plantations. 


\section{Appendix A}

Table A1. Forest area, carbon stock, and carbon sinks of planted forests for six regions in China from 1977 to 2008.

\begin{tabular}{|c|c|c|c|c|c|c|c|}
\hline Period & China & North & Northeast & East & South central & Southwest & Northwest \\
\hline \multicolumn{8}{|c|}{ Area $\left(10^{4} \mathrm{ha}\right)$} \\
\hline $1977-1981$ & 1595.2 & 166.2 & 298.2 & 365.4 & 586.1 & 101.9 & 77.3 \\
\hline 1984-1988 & 2347.2 & 244.7 & 497.8 & 583.0 & 595.9 & 277.1 & 148.7 \\
\hline 1989-1993 & 2675.2 & 308.7 & 456.8 & 680.8 & 761.9 & 339.1 & 127.9 \\
\hline 1994-1998 & 2914.4 & 309.5 & 474.4 & 717.5 & 878.5 & 396.7 & 137.9 \\
\hline 1999-2003 & 3229.4 & 386.2 & 461.9 & 769.2 & 976.3 & 495.9 & 139.8 \\
\hline 2004-2008 & 3999.9 & 494.4 & 536.6 & 928.8 & 1235.8 & 633.3 & 170.9 \\
\hline Net change & 2404.6 & 328.2 & 238.3 & 563.4 & 649.6 & 531.4 & 93.6 \\
\hline \multicolumn{8}{|c|}{ C stock $(\operatorname{Tg} \mathrm{C})$} \\
\hline $1977-1981$ & 249.5 & 23.5 & 57.1 & 52.2 & 88.2 & 18.5 & 10.1 \\
\hline 1984-1988 & 418.0 & 41.4 & 105.7 & 105.0 & 96.5 & 47.1 & 22.3 \\
\hline 1989-1993 & 525.8 & 55.6 & 105.5 & 136.0 & 138.1 & 62.1 & 28.4 \\
\hline 1994-1998 & 642.4 & 63.0 & 130.7 & 153.2 & 171.0 & 87.3 & 37.2 \\
\hline 1999-2003 & 836.1 & 82.5 & 150.3 & 203.7 & 231.0 & 130.8 & 37.7 \\
\hline 2004-2008 & 1067.1 & 104.8 & 179.9 & 261.4 & 299.0 & 173.0 & 49.1 \\
\hline Net change & 817.6 & 81.4 & 122.8 & 209.2 & 210.8 & 154.5 & 39.0 \\
\hline \multicolumn{8}{|c|}{$\mathrm{C}$ density $\left(\mathrm{Mg} \mathrm{Cha}^{-1}\right)$} \\
\hline $1977-1981$ & 15.6 & 14.1 & 19.1 & 14.3 & 15.0 & 18.1 & 13.1 \\
\hline 1984-1988 & 17.8 & 16.9 & 21.2 & 18.0 & 16.2 & 17.0 & 15.0 \\
\hline 1989-1993 & 19.7 & 18.0 & 23.1 & 20.0 & 18.1 & 18.3 & 22.2 \\
\hline 1994-1998 & 22.0 & 20.4 & 27.5 & 21.4 & 19.5 & 22.0 & 27.0 \\
\hline 1999-2003 & 25.9 & 21.4 & 32.5 & 26.5 & 23.7 & 26.4 & 27.0 \\
\hline 2004-2008 & 26.7 & 21.2 & 33.5 & 28.1 & 24.2 & 27.3 & 28.7 \\
\hline Net change & 11.0 & 7.1 & 14.4 & 13.9 & 9.2 & 9.2 & 15.6 \\
\hline \multicolumn{8}{|c|}{$\mathrm{C}$ sink $\left(\mathrm{Tg} \mathrm{C} \mathrm{yr}^{-1}\right)$} \\
\hline 1981-1988 & 24.1 & 2.6 & 6.9 & 7.5 & 1.2 & 4.1 & 1.7 \\
\hline 1988-1993 & 21.6 & 2.8 & 0.0 & 6.2 & 8.3 & 3.0 & 1.2 \\
\hline 1993-1998 & 23.3 & 1.5 & 5.0 & 3.4 & 6.6 & 5.0 & 1.7 \\
\hline $1998-2003$ & 38.7 & 3.9 & 3.9 & 10.1 & 12.0 & 8.7 & 0.1 \\
\hline 2003-2008 & 46.2 & 4.5 & 5.9 & 11.5 & 13.6 & 8.4 & 2.3 \\
\hline
\end{tabular}




\section{Appendix B}

Table B1. Forest area, carbon stock, and carbon sinks of natural forests for six regions in China from 1977 to 2008.

\begin{tabular}{|c|c|c|c|c|c|c|c|}
\hline Period & China & North & Northeast & East & South central & Southwest & Northwest \\
\hline \multicolumn{8}{|c|}{ Area $\left(10^{4} \mathrm{ha}\right)$} \\
\hline $1977-1981$ & 10755.0 & 1682.8 & 2655.6 & 1160.5 & 1587.2 & 2837.3 & 831.5 \\
\hline 1984-1988 & 10822.0 & 1655.1 & 2556.5 & 1140.3 & 1546.4 & 3055.9 & 867.9 \\
\hline 1989-1993 & 11296.2 & 1688.3 & 2673.6 & 1223.3 & 1684.1 & 3193.5 & 833.3 \\
\hline 1994-1998 & 10326.1 & 1451.6 & 2295.5 & 1186.4 & 1620.3 & 3012.9 & 759.5 \\
\hline 1999-2003 & 11049.3 & 1617.0 & 2364.4 & 1257.5 & 1743.7 & 3306.2 & 760.4 \\
\hline 2004-2008 & 11559.1 & 1688.5 & 2464.1 & 1303.8 & 1851.5 & 3425.9 & 825.4 \\
\hline Net change & 804.1 & 5.7 & -191.5 & 143.2 & 264.3 & 588.5 & -6.1 \\
\hline \multicolumn{8}{|c|}{ C stock (Tg C) } \\
\hline $1977-1981$ & 4467.8 & 533.2 & 1192.8 & 332.3 & 368.2 & 1701.2 & 340.0 \\
\hline 1984-1988 & 4466.8 & 552.2 & 1150.8 & 272.0 & 331.5 & 1810.2 & 350.3 \\
\hline 1989-1993 & 4876.5 & 573.7 & 1203.2 & 292.8 & 367.3 & 2089.4 & 350.0 \\
\hline 1994-1998 & 4745.5 & 558.3 & 1126.4 & 282.0 & 374.5 & 2058.0 & 346.3 \\
\hline 1999-2003 & 5026.4 & 618.6 & 1122.5 & 311.9 & 422.0 & 2195.7 & 355.7 \\
\hline 2004-2008 & 5360.0 & 655.3 & 1182.3 & 371.5 & 480.3 & 2292.3 & 378.3 \\
\hline Net change & 892.1 & 122.0 & -10.5 & 39.2 & 112.1 & 591.1 & 38.3 \\
\hline \multicolumn{8}{|c|}{$\mathrm{C}$ density $\left(\mathrm{MgCha}^{-1}\right)$} \\
\hline 1977-1981 & 41.5 & 31.7 & 44.9 & 28.6 & 23.2 & 60.0 & 40.9 \\
\hline 1984-1988 & 41.3 & 33.4 & 45.0 & 23.9 & 21.4 & 59.2 & 40.4 \\
\hline 1989-1993 & 43.2 & 34.0 & 45.0 & 23.9 & 21.8 & 65.4 & 42.0 \\
\hline 1994-1998 & 46.0 & 38.5 & 49.1 & 23.8 & 23.1 & 68.3 & 45.6 \\
\hline 1999-2003 & 45.5 & 38.3 & 47.5 & 24.8 & 24.2 & 66.4 & 46.8 \\
\hline 2004-2008 & 46.4 & 38.8 & 48.0 & 28.5 & 25.9 & 66.9 & 45.8 \\
\hline Net change & 4.8 & 7.1 & 3.1 & -0.1 & 2.7 & 7.0 & 4.9 \\
\hline \multicolumn{8}{|c|}{$\mathrm{C} \operatorname{sink}\left(\mathrm{Tg} \mathrm{C} \mathrm{yr}^{-1}\right)$} \\
\hline 1981-1988 & -0.1 & 2.7 & -6.0 & -8.6 & -5.3 & 15.6 & 1.5 \\
\hline 1988-1993 & 81.9 & 4.3 & 10.5 & 4.2 & 7.2 & 55.8 & 0.0 \\
\hline 1993-1998 & -26.2 & -3.1 & -15.4 & -2.2 & 1.4 & -6.3 & -0.7 \\
\hline 1998-2003 & 56.2 & 12.1 & -0.8 & 6.0 & 9.5 & 27.5 & 1.9 \\
\hline 2003-2008 & 66.7 & 7.3 & 12.0 & 11.9 & 11.7 & 19.3 & 4.5 \\
\hline
\end{tabular}


Appendix C

Table C1. Changes in forest area, carbon density, and carbon stock for planted forests in provinces of China for the period 1977-2008.

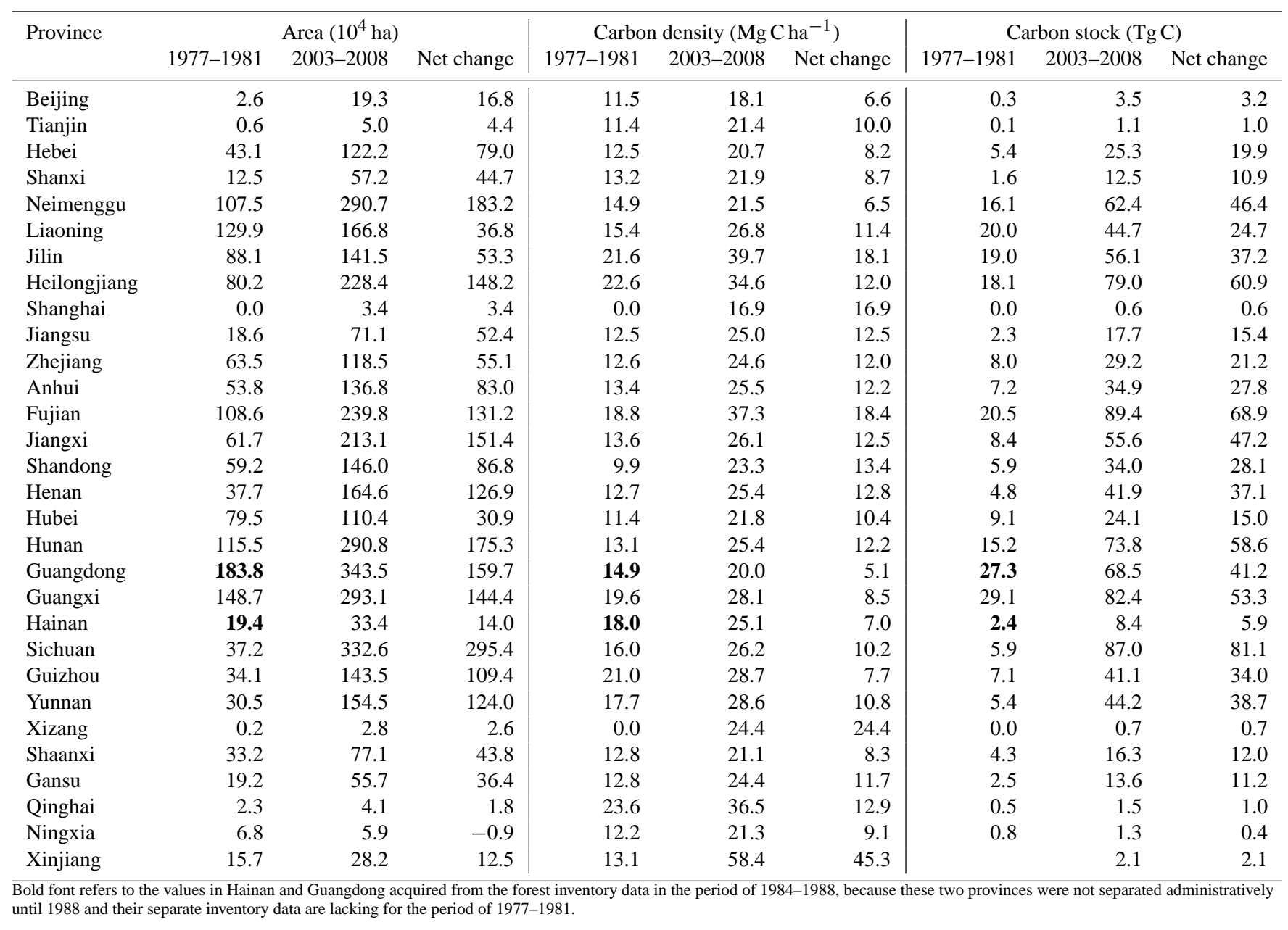


Appendix D

Table D1. Changes in forest area, carbon density, and carbon stock for natural forests in provinces of China for the period 1977-2008.

\begin{tabular}{|c|c|c|c|c|c|c|c|c|c|}
\hline \multirow[t]{2}{*}{ Province } & \multicolumn{3}{|c|}{ Area $\left(10^{4} \mathrm{ha}\right)$} & \multicolumn{3}{|c|}{ Carbon density $\left(\mathrm{MgC} \mathrm{ha}^{-1}\right)$} & \multicolumn{3}{|c|}{ Carbon stock $(\mathrm{Tg} \mathrm{C})$} \\
\hline & 1977-1981 & 2003-2008 & Net change & 1977-1981 & 2003-2008 & Net change & 1977-1981 & $2003-2008$ & Net change \\
\hline Beijing & 5.8 & 16.2 & 10.4 & 15.5 & 17.9 & 2.4 & 0.9 & 2.9 & 2.0 \\
\hline Hebei & 103.0 & 166.1 & 63.0 & 16.1 & 17.5 & 1.3 & 16.6 & 29.0 & 12.4 \\
\hline Shanxi & 77.1 & 115.2 & 38.1 & 27.2 & 28.5 & 1.3 & 21.0 & 32.8 & 11.9 \\
\hline Neimenggu & 1496.3 & 1390.5 & -105.8 & 33.1 & 42.5 & 9.4 & 494.7 & 590.4 & 95.8 \\
\hline Heilongjiang & 1817.9 & 1684.3 & -133.6 & 43.1 & 43.7 & 0.6 & 783.7 & 736.5 & -47.2 \\
\hline Shanghai & 0.2 & 0.0 & -0.2 & 8.8 & 0.0 & -8.8 & 0.0 & 0.0 & 0.0 \\
\hline Jiangsu & 2.9 & 3.4 & 0.4 & 12.5 & 18.4 & 5.9 & 0.4 & 0.6 & 0.3 \\
\hline Zhejiang & 227.7 & 275.1 & 47.4 & 19.2 & 21.5 & 2.3 & 43.8 & 59.2 & 15.4 \\
\hline Anhui & 135.7 & 134.0 & -1.7 & 20.4 & 25.2 & 4.8 & 27.6 & 33.8 & 6.1 \\
\hline Fujian & 339.1 & 326.2 & -12.9 & 39.2 & 39.5 & 0.4 & 132.8 & 128.9 & -3.8 \\
\hline Hunan & 379.7 & 435.8 & 56.1 & 21.5 & 21.8 & 0.3 & 81.8 & 95.0 & 13.2 \\
\hline Guangdong & 320.0 & 335.3 & 15.3 & 19.7 & 27.1 & 7.4 & 62.9 & 90.8 & 27.9 \\
\hline Guangxi & 394.9 & 513.6 & 118.7 & 26.3 & 27.9 & 1.6 & 103.8 & 143.5 & 39.6 \\
\hline Hainan & 49.5 & 50.7 & 1.3 & 49.4 & 56.7 & 7.3 & 24.4 & 28.8 & 4.3 \\
\hline Sichuan & 765.8 & 1014.7 & 248.9 & 60.5 & 62.3 & 1.8 & 463.7 & 632.3 & 168.6 \\
\hline Guizhou & 225.6 & 254.6 & 29.0 & 28.6 & 28.4 & -0.1 & 64.5 & 72.4 & 7.9 \\
\hline Yunnan & 1056.7 & 1318.2 & 261.5 & 52.2 & 53.4 & 1.2 & 551.2 & 703.6 & 152.4 \\
\hline Xizang & 789.2 & 838.4 & 49.1 & 78.8 & 105.4 & 26.6 & 621.9 & 884.0 & 262.1 \\
\hline Shaanxi & 487.6 & 490.0 & 2.3 & 32.4 & 36.0 & 3.6 & 158.0 & 176.5 & 18.6 \\
\hline Gansu & 198.9 & 157.8 & -41.1 & 43.7 & 52.3 & 8.5 & 87.0 & 82.4 & -4.5 \\
\hline Qinghai & 21.9 & 31.4 & 9.6 & 41.9 & 52.1 & 10.2 & 9.2 & 16.4 & 7.2 \\
\hline Ningxia & 4.1 & 5.2 & 1.1 & 22.6 & 31.3 & 8.7 & 0.9 & 1.6 & 0.7 \\
\hline
\end{tabular}


Appendix E: The estimation methods for forest area and stand volume in CFID

\section{E1 Forest area estimation}

In the forest inventory of China, the systematic sampling was conducted at the provincial level. Based on the sampling method, the ratio of forest area $\left(P_{i}\right)$ for a certain forest type (i) can be expressed as

$p_{i}=\frac{m_{i}}{n}$

$S_{p_{i}}=\sqrt{\frac{p_{i}\left(1-p_{i}\right)}{n-1}}$,

where $n$ represents the number of all the sampling plots, $m_{i}$ represents the number of plots classified as type $i$ (including various types of land categories, vegetation types, forest types, and other land classification attributions), and $S_{p i}$ represents the standard deviation of $P_{i}$. Then, the area of forest $i \hat{A}_{i}$ can be estimated by the following equation:

$\hat{A}_{i}=A \cdot p_{i}$,

where $A$ refers to the overall area in the forest inventory for one province, and the total area is equal to the sum area of all types of forests. The limit of error for the area estimation is calculated by the following equation:

$\Delta_{A_{i}}=A \cdot t_{\alpha} \cdot S_{p_{i}}$,

where $t_{a}$ is the reliability index, and the estimation interval can be expressed as $\hat{A}_{i} \pm \Delta_{A_{i}}$. The sampling precision $\left(P_{A i}\right)$ can be expressed as

$P_{A_{i}}=\left(1-\frac{t_{a} \cdot S_{p_{i}}}{p_{i}}\right) \cdot 100 \%$.

\section{E2 Forest volume estimation}

The mean stand volume for forest $i$ can be expressed as

$\bar{V}_{i}=\frac{1}{n} \sum_{j=1}^{n} V_{i j}$,

where $V_{i j}$ represents the stand volume of plot $j$ for forest $i$. The sampling variance is calculated as

$$
S_{V_{i}}^{2}=\frac{1}{n-1} \sum_{j=1}^{n}\left(V_{i j}-\bar{V}_{i}\right)^{2}
$$

$S_{\bar{V}_{i}}=\frac{S_{V_{i}}}{\sqrt{n}}$

The overall stand volumes for forest $i$ can be estimated as $\hat{V}_{i}=\frac{A}{a} \cdot \bar{V}_{i}$, where $A$ is the overall area in the forest inventory for one province, and $a$ is the area of the sampling plot.

The limit of error for the overall estimation of forest $i$ can be calculated by the following equation:

$\Delta_{V_{i}}=\frac{A}{a} \cdot t_{a} \cdot S_{\bar{V}_{i}}$,

where $t_{a}$ is the reliability index, and the estimation interval can be expressed as $\hat{V}_{i} \pm \Delta_{V_{i}}$.

The sampling precision $\left(P_{v i}\right)$ can be expressed as

$P_{V_{i}}=\left(1-\frac{t_{a} \cdot S_{V_{i}}}{\bar{V}_{i}}\right) \cdot 100 \%$. 
Author contributions. J. Fang, J. Zhu, and P. Li designed the research; P. Li, J. Zhu, H. Hu, Z. Guo, and J. Fang performed the research; P. Li, J. Zhu, and J. Fang analyzed data; J. Fang, Y. Pan, and R. Birdsey contributed new analytic tools; and P. Li and J. Zhu prepared the manuscript with contributions from all co-authors.

Acknowledgements. This work was supported by the National Natural Science Foundation of China (nos. 31321061 and 31330012), the Chinese Academy of Sciences (XDA05050300), the US Forest Service (07-JV-11242300-117), and the State Forestry Administration of China (2013-R13).

Edited by: C. A. Williams

\section{References}

Birdsey, R., Pregitzer, K., and Lucier, A.: Forest carbon management in the United States, J. Environ. Qual., 35, 1461-1469, 2006.

Bonan, G. B.: Forests and climate change: forcings, feedbacks, and the climate benefits of forests, Science, 320, 1444-1449, 2008.

Brown, S. L. and Schroeder, P. E.: Spatial patterns of aboveground production and mortality of woody biomass for eastern U.S. forests, Ecol. Appl., 9, 968-980, 1999.

Brown, S. L., Sathaye, J., Cannell, M., and Kauppi, P.: Mitigation of carbon emissions to the atmosphere by forest management, Commonw. For. Rev., 75, 80-91, 1996.

Brown, S. L., Schroeder, P., and Birdsey, R.: Aboveground biomass distribution of US eastern hardwood forests and the use of large trees as an indicator of forest development, For. Ecol. Manag., 96, 37-47, 1997.

Brown, S. L., Schroeder, P., and Kern, J. S.: Spatial distribution of biomass in forests of the eastern USA, For. Ecol. Manag., 123, 81-90, 1999.

Du, Z., Wang, W., Zeng, W., and Zeng, H.: Nitrogen Deposition Enhances Carbon Sequestration by Plantations in Northern China, PLoS ONE, 9, e87975, doi:10.1371/journal.pone.0087975, 2014.

Fang, J. and Chen, A.: Dynamic forest biomass carbon pools in China and their significance, Acta Bot. Sin., 43(9), 967-973, 2000.

Fang, J., Liu, G., and Xu, S.: Biomass and net production of forest vegetation in China [J], Acta Ecol. Sin., 16, 497-508, 1996.

Fang, J., Wang, G. G., Liu, G., and Xu, S.: Forest biomass of china: an estimate based on the biomass - volume relationship, Ecol. Appl., 8, 1084-1091, 1998.

Fang, J., Chen, A., Peng, C., Zhao, S., and Ci, L.: Changes in forest biomass carbon storage in China between 1949 and 1998, Science, 292, 2320-2322, 2001.

Fang, J., Piao, S., He, J., and Ma, W.: Increasing terrestrial vegetation activity in China, 1982-1999, Sci. China C Life Sci., 47, 229-240, 2004.

Fang, J., Oikawa, T., Kato, T., Mo, W., and Wang, Z.: Biomass carbon accumulation by Japan's forests from 1947 to 1995, Global Biogeochem. Cy., 19, GB2004, doi:10.1029/2004GB002253, 2005.
Fang, J., Guo, Z., Piao, S., and Chen, A.: Terrestrial vegetation carbon sinks in China, 1981-2000, Sci. China Ser. Earth Sci., 50, 1341-1350, 2007.

Fang, J., Tang, Y., and Son, Y.: Why are East Asian ecosystems important for carbon cycle research?, Sci. China Life Sci., 53, 753-756, 2010.

Fang, J., Guo, Z., Hu, H., Kato, T., Muraoka, H., and Son, Y.: Forest biomass carbon sinks in East Asia, with special reference to the relative contributions of forest expansion and forest growth, Glob. Change Biol., 20, 2019-2030, 2014a.

Fang, J., Kato, T., Guo, Z., Yang, Y., Hu, H., Shen, H., Zhao, X., Kishimoto-Mo, A. W., Tang, Y., and Houghton, R. A.: Evidence for environmentally enhanced forest growth, P. Natl. Acad. Sci. USA, 111, 9527-9532, 2014b.

FAO: Global Forest Resources Assessment 2005: Progress Towards Sustainable Forest Management, FAO Forestry Paper No. 147, Rome, Italy, 2006.

Guo, Z., Fang, J., Pan, Y., and Birdsey, R.: Inventory-based estimates of forest biomass carbon stocks in China: A comparison of three methods, For. Ecol. Manag., 259, 1225-1231, 2010.

Guo, Z., Hu, H., Li, P., Li, N., and Fang, J.: Spatio-temporal changes in biomass carbon sinks in China's forests from 1977 to 2008, Sci. China Life Sci., 56, 661-671, 2013.

$\mathrm{Hu}, \mathrm{H}$. and Wang, G. G.: Changes in forest biomass carbon storage in the South Carolina Piedmont between 1936 and 2005, For. Ecol. Manag., 255, 1400-1408, 2008.

Janssens, I. A., Freibauer, A., Ciais, P., Smith, P., Nabuurs, G.-J., Folberth, G., Schlamadinger, B., Hutjes, R. W. A., Ceulemans, R., Schulze, E.-D., Valentini, R., and Dolman, A. J.: Europe's Terrestrial Biosphere Absorbs 7 to $12 \%$ of European Anthropogenic $\mathrm{CO}_{2}$ Emissions, Science, 300, 1538-1542, , 2003.

Kauppi, P. E., Ausubel, J. H., Fang, J., Mather, A. S., Sedjo, R. A., and Waggoner, P. E.: Returning forests analyzed with the forest identity, P. Natl. Acad. Sci. USA, 103, 17574-17579, 2006.

Lei, J.: Forest resource of China, China Forestry Publishing House, Beijing, 2005.

Leith, H. and Whittaker, R.: Primary production of the biosphere, Ecol Stud., 14, Springer, NY, 1975.

Li, W.: Degradation and restoration of forest ecosystems in China, For. Ecol. Manag., 201, 33-41, 2004.

Liu, Y.: Study on Post-evaluation Theory and Application of the Forestry Ecological Engineering in China, Beijing Forestry University, Beijing, 2006

Magnani, F., Mencuccini, M., Borghetti, M., Berbigier, P., Berninger, F., Delzon, S., Grelle, A., Hari, P., Jarvis, P. G., Kolari, P., Kowalski, A. S., Lankreijer, H., Law, B. E., Lindroth, A., Loustau, D., Manca, G., Moncrieff, J. B., Rayment, M., Tedeschi, V., Valentini, R., and Grace, J.: The human footprint in the carbon cycle of temperate and boreal forests, Nature, 447, 849-851, 2007.

Malhi, Y., Meir, P., and Brown, S.: Forests, carbon and global climate, Philos. T. Roy. Soc. A, 360, 1567-1591, 2002.

McKinley, D. C., Ryan, M. G., Birdsey, R. A., Giardina, C. P., Harmon, M. E., Heath, L. S., Houghton, R. A., Jackson, R. B., Morrison, J. F., Murray, B. C., Pataki, D. E., and Skog, K. E.: A synthesis of current knowledge on forests and carbon storage in the United States, Ecol. Appl., 21, 1902-1924, doi:10.1890/100697.1, 2011. 
Chinese Ministry of Forestry: Forest Resource Statistics of China (1977-1981), Department of Forest Resource and Management, Chinese Ministry of Forestry, Beijing, China, 1983.

Chinese Ministry of Forestry: Forest Resource Statistics of China (1984-1988), Department of Forest Resource and Management, Chinese Ministry of Forestry, Beijing, China, 1989.

Chinese Ministry of Forestry: Forest Resource Statistics of China (1989-1993), Department of Forest Resource and Management, Chinese Ministry of Forestry, Beijing, China, 1994.

Chinese Ministry of Forestry: Forest Resource Statistics of China (1994-1998), Department of Forest Resource and Management, Chinese Ministry of Forestry, Beijing, China, 2000.

Chinese Ministry of Forestry: Forest Resource Statistics of China (1999-2003), Department of Forest Resource and Management, Chinese Ministry of Forestry, Beijing, China, 2005.

Chinese Ministry of Forestry: Forest Resource Report of China The 7th National Forest Resources Inventory, China Forestry Publishing House, Beijing, China, 2010.

Nabuurs, G.-J., Schelhaas, M.-J., Mohren, G. M. J., and Field, C. B.: Temporal evolution of the European forest sector carbon sink from 1950 to 1999, Glob. Change Biol., 9, 152-160, doi:10.1046/j.1365-2486.2003.00570.x, 2003.

Pan, Y., Birdsey, R. A., Fang, J., Houghton, R., Kauppi, P. E., Kurz, W. A., Phillips, O. L., Shvidenko, A., Lewis, S. L., Canadell, J. G., Ciais, P., Jackson, R. B., Pacala, S. W., McGuire, A. D., Piao, S., Rautiainen, A., Sitch, S., and Hayes, D.: A Large and Persistent Carbon Sink in the World's Forests, Science, 333, 988 993, 2011.
Pan, Y., Birdsey, R. A., Phillips, O. L., and Jackson, R. B.: The Structure, Distribution, and Biomass of the World's Forests, Annu. Rev. Ecol. Evol. Syst., 44, 593-622, 2013.

Peng, S., Chen, A., Xu, L., Cao, C., Fang, J., Myneni, R. B., Pinzon, J. E., Tucker, C. J., and Piao, S.: Recent change of vegetation growth trend in China, Environ. Res. Lett., 6, 044027, doi:10.1088/1748-9326/6/4/044027, 2011.

Shi, L., Zhao, S., Tang, Z., and Fang, J.: The Changes in China's Forests: An Analysis Using the Forest Identity, PLoS ONE, 6, e20778, doi:10.1371/journal.pone.0020778, 2011.

Waggoner, P. E.: Using the Forest Identity to Grasp and Comprehend the Swelling Mass of Forest Statistics, Int. For. Rev., 10, 689-694, 2008.

Wang, G., Innes, J. L., Lei, J., Dai, S., and Wu, S. W.: China's Forestry Reforms, Science, 318, 1556-1557, 2007.

Watson, R. T., Noble, I. R., Bolin, B., Ravindranath, N. H., Verardo, D. J., and Dokken, D. J.: Land use, land-use change and forestry: a special report of the Intergovernmental Panel on Climate Change, Cambridge University Press, Cambridge, 2000.

Xiao, X.: Forest inventory of China, China Forestry Publishing House, Beijing, 2005.

Xu, B., Guo, Z., Piao, S., and Fang, J.: Biomass carbon stocks in China's forests between 2000 and 2050: A prediction based on forest biomass-age relationships, Sci. China Life Sci., 53, 776783, 2010. 